\title{
TANTANGAN PENERAPAN SISTEM BELAJAR ONLINE BAGI MAHASISWA DITENGAH PANDEMIK COVID-19
}

\author{
Hengki Mangiring Parulian Simarmata ${ }^{1)}$, Poltak Pardamean Simarmata ${ }^{2)}$ \\ ${ }^{1}$ Administasi Perkantoran, Politeknik Bisnis Indonesia \\ email: hengkisimarmata.mm@gmail.com \\ ${ }^{2}$ Manajemen, Sekolah Tinggi Akuntansi dan Manajemen Indonesia \\ email: poltak.pardamean@sbm-itb.ac.id
}

\begin{abstract}
The Covid-19 virus epidemic that hit Indonesia had an impact on policies in changing creative, adaptive and innovative teaching and learning processes. In preventing the spread of the covid-19 virus, the Indonesian government closed schools and universities for a while. Campus management conducts health protocols without reducing teaching and learning process between students and lecturers. One of the activities carried out on campus is by conducting online or online classes using various applications such as zoom and E-learning. This research method is done by qualitative methods. Data obtained by conducting a survey of 50 Indonesian Business Polytechnic students online. The purpose of this research is to get information about problems and obstacles faced by students when conducting the online learning process. This research is expected to be able to provide input for higher education institutions in managing and providing policies during the Covid-19 pandemic.
\end{abstract}

Keywords: Student issues, Online learning, Covid-19

\section{PENDAHULUAN}

Covid-19 merupakan penyakit pernafasan akut yang disebabkan oleh Coronavirus SarsCov-2 (severe acute respiratory syndrome coronavirus 2). Virus yang pertama kali ditemukan di Kota Wuhan Cina menjadi ancaman pandemik bagi masyarakat global. Virus ini cepat menyebar dan diyatakan sebagai penyakit pandemik oleh WHO pada tanggal 11 Maret 2020. Covid-19 atau virus corona merupakan virus yang menyerang sistem pernapasan dimana virus dapat menyebabkan gangguan sistem pernafasan, inveksi paru-paru akut dan dapat berujung pada kematian.

Kematian yang terus meningkat sejak pengumuman pasien pertama positif Covid-19 diberitakan pada awal maret 2020 oleh Pemerintah Indonesia. Organisasi Kesehatan Dunia (WHO) merekomendasikan agar dilakukannya pemberhentian sementara kegiatan yang dapat menimbulkan penyebaran virus secara masif. Untuk mengatasi penyebaran Covid-19 beberapa kebijakan yang dilakukan dengan menghentikan atau membatasi aktivitas masyarakat. Beberapa kebijakan seperti Lockdown, Sosial Distancing, Physical Distancing dan penerapan Pembatasan Sosial Skala Besar (PSBB). Pemerintah Indonesia melakukan beberapa kebijakan seperti Intruksi Presiden Republik Indonesia untuk Work From Home (WFH) bekerja dari rumah. Bekerja dari rumah atau work from home yang dilaksanakan saat ini merupakan tindak lanjut atas imbauan Presiden Joko Widodo pada konferensi pers di Istana Bogor Jawa Barat pada tanggal 15 Maret 2020. Kemudian kebijakan yang dilakukan oleh pemerintah adalah melakukan PSBB untuk melindungi masyarakat dari penularan virus coron. Hal ini bersadarkan pada Peraturan Pemerintah (PP 21 Tahun 2020). Presiden mengimbau agar dapat meminimalisasi penyebaran virus corona tipe baru (SARS-CoV2) penyebab covid-19, masyarakat diminta untuk bekerja, belajar, dan beribadah dari rumah[1].

Pada masa pandemi covid-19 pendidikan kita memasuki masa ketakterdugaan dan ketidakpastian. Perlu adanya adaptasi bagi pendidikan di Indonesia terhadap kondisi 
pandemik covid-19. Oleh karena itu perlunya kebijakan pada proses pembelajaran di Perguruan Tinggi agar semakin otonom dan fleksibel. Dengan menciptakan kultur belajar yang inovatif, tidak mengekang, dan sesuai dengan kebutuhan mahasiswa.

Kebijakan yang dilakukan didunia pendidikan salah satunya adalah melakukan proses belajar-mengajar di rumah atau belajar online. Siap maupun tidak siap semua pendidik dan pelajar harus mampu menggunakan dan menguasai teknologi saat proses belajar mengajar.

Rumusan masalah dari penelitian ini adalah apa yang menjadi tantangan dan kendala mahasiswa Politeknik Bisnis Indonesia selama mengadakan proses belajar dengan daring saat pandemik covid-19. Harapan dari penelitian ini untuk memberikan masukan kepada pimpinan perguruan tinggi didalam mengambil kebijakan saat proses belajar mengajar secara daring yang dilakukan.

\section{Belajar Secara Daring}

Kondisi pandemik covid-19 menimbulkan tantangan bagi dunia pendidikan yaitu dengan perubahan dalam proses pembelajaran di semua jenjang pendidikan. Oleh karena itu Perguruan Tinggi perlu menciptakan pembelajaran yang kreatif, inovatif dan adaptif sehingga proses belajar mengajar tetap dapat dilakukan secara optimal.

Kebijakan Menteri Pendidikan dan Kebudayaan RI, Bapak Nadiem Anwar Makarin melalui surat edaran Nomor 4 tahun 2020 tentang Pelaksanaan Kebijakan Pendidikan dalam Masa Darurat Penyebaran Coronavirus Disease (Covid-19) dimana salah satu kebijakan dijelakan adalah cara belajar mengajar siswa dan guru dari rumah. Beberapa kebijakan pada point 2 yang disampaikan yaitu proses belajar dari rumah dilaksanakan melalui daring/jarak jauh. Pembelajaran dirumah difokuskan pada pendidikan kecakapan hidup [2].

Aktivitas dan tugas pembelajaran dapat bervariasi sesuai dengan minat dan kondisi masing-masing dengan mempertimbangkan kesetersediaan akses/ fasilitas belajar dirumah. Kegiatan ini dilakukan dalam rangka pencegahan penyebaran virus covid-19.
Sistem pembelajaran online dianggap mampu membantu proses belajar mengajar. Belajar sendiri atau belajar daring memberikan tantangan baru bagi pengajar hal ini disebabkan karena sebelumnya kegiatan proses belajar mengajar dikelas. Kelas terdiri dari pengajar dan pelajar dengan sumber pelajaran dari buku. Pembelajaran diharapkan mahasiswa mampu mencari tau, merumuskan masalah dan mencari solusi, melatih mengambil keputusan analitis, pentingnya kerjasama dan kolaborasi dalam penyelesaian masalah.

Dengan adanya sistem belajar online maka metode pembelajaran dapat dilakukan dengan vidio tutorial, vidio conferensi, live chat, vidio call, tugas online, quis atau ujian online. Contoh media yang digunakan dapat berupa google class room, ruang guru, TVRI, zoom, $e$ learning, whatsapp grup, zenius, quipper, cakap, kipin school dan lainnya. Sehingga perlunya dukungan perangkat dalam pelaksanaan pembelajaran online seperti telepon pintar, latop, tablet dan komputer [3].

Sedangkan akses yang dilakukan untuk mengakses kuliah online dapat dari rumah, area publik dan kampus, Akses jaringan yang sering digunakan untuk menjalankan kuliah online adalah telepon seluler, wifi rumah dan wifi publik

Milman dalam Firman dan Rahayu [3] menjelaska bahwa kegiatan proses belajar mengajar dengan menggunakan teknologi digital sangat dimungkinkan sehingga dosen dan mahasiswa dapat melakukan proses belajar mengajar ditempat yang berbeda. Menurut Setyosari dalam Khasanah, dkk [4], bahwa kegiatan belajar dengan menggunakan online memiliki beberapa keuntungan yaitu kemudahan dalam akses belajar, mahasiswa dapat langsung berhubungan dengan pengajar. Sedangkan menurut Setiawan [5] kelebihan dari belajar jarak jauh adalah memperluas akses pendidikan ke masyarakat umum, jadwal lebih fleksibel, pengalaman dalam proses belajar mengajar lebih inovatif sedangkan kekurangannya adalah gangguan di rumah, interaksi saat proses belajar mengajar

Menurut Aji [6] kendala yang dihadapi dengan melakukan metode daring adalah (a) Keterbatasan penguasaan teknologi informasi; 
(b) Sarana dan prasarana yang kurang memadai;

(c) Akses internet yang terbatas; (d) Kurang siapnya penyedia anggaran. Sedangkan menurut Pujilestari [7] kurangnya kesiapan dalam penggunaan media teknologi disebabkan karena sumber daya manusia yang tidak trampil dibidang teknologi, dan infrastuktur telekomunikasi yang tidak memadai

\section{METODE PENELITIAN}

Penelitian ini merupakan penelitian kualitatif. Data primer diambil dengan melakukan observasi dan survey kepada mahasiswa Politeknik Bisnis Indonesia. Pematangsiantar Teknik wawancara yang dilakukan dengan menggunakan telepon dan whatsapp. Data sekunder diperoleh dengan studi pustaka dari jurnal penelitian tentang covid 19 dan infomasi media yang berhubungan berita covid-19. Populasi dalam penelitian ini adalah mahasiswa Politeknik Bisnis Indonesia Pematangsiantar dengan jumlah sampel sebanyak 50 orang yang dianggap mampu memberikan informasi tetang topik penelitian, Sampel diambil dengan teknik random sampling dimana mahasiswa dianggap mampu memberikan informasi sesuai dengan topik yang dibahas. Hasil wawancara kemudian dianalisis. Analisis yang dilakukan dengan cara pengumpulan data, reduksi data, display data dan kesimpulan.

\section{HASIL DAN PEMBAHASAN}

Menurtu Wijaya dalam Dewi [8] belajar dirumah diharapkan mampu memberikan kemudahan didalam proses belajar mengajar, hal ini dikarenakan bahwa proses belajar mengajar dapat dilakukan kapan saja dan dimana saja dan didukung dengan teknologi yang digunakan untuk belajar online atau jarak jauh. Namun pada kenyataannya ketidak siapan kampus dan mahasiswa melakukan adaptasi saat proses belajar mengajar mengakibatkan banyaknya kendala-kendala yang dihadapi saat proses belajar mengajar. Budaya belajar sendiri yang sebelumnya jarang dilakukan mengakibatkan mahasiswa merasa sulit untuk beradaptasi dengan penggunaan teknologi pasa masa pandemik Covid-19 ini. Adanya gagap teknologi mahasiswa dan pengajar disebabkan karena kurangnya pemahaman didalam penggunaan teknologi. Disamping itu orang tua selalu menganggap bahwa mahasiswa tidak benarbenar belajar karena tidak bisa melihat aktivitas proses belajar mengajar.

\section{Tantangan dan Kendala Mahasiswa}

Perkuliahan yang dianggap membebani karena materi yang disampaikan tidak sepenuhnya dimengerti oleh mahasiswa. Disamping itu beban akibat tugas onlie yang diberikan dengan batas waktu tertentu, ujian/quiz online ,dan total biaya kuota internet yang sering dihabiskan untuk kuliah online padahal kondisi perekonomian mahasiswa tidak mendukung saaat pandemik covid-19 ini.

\section{a. Proses belajar mengajar}

Dari hasil penelitian yang dilakukan oleh Dr Agung Sakti Pribadi yang diseminarkan di Webinar dijelaskan bahwa $44.83 \%$ mahasiswa merasa terbebani belajar online dibandingkan dengan tatap muka. Pemahaman materi yang sulit dipahami dengan waktu kelas yang diberikan dan pengerjaan diskusi terbatas. Proses belajar mengajar dengan tatap muka saja mahasiswa bisa tidak mengerti apalagi kegiatan yang dilakukan secara online dengan waktu yang sangat terbatas. Materi yang sulit dimengerti terutama materi menghitung, bahkan beberapa dosen memberikan materi yang cukup banyak di online atau e-learning tanpa penjelasan sehingga mahasiswa harus belajar sendiri dan sulit untuk memahami. Kemudian kendala lainnya adalah sulitnya berkomunikasi dan berdiskusi dengan dosen pada saat proses belajar berlangsung sehingga banyak yang miskomunikasi, beberapa mahasiswa menganggap respon dosen saat berdiskusi sangat lambat

Akses yang digunakan untuk berkomunikasi saat belajar seperti handpone dan latop juga dianggap menjadi kendala karena tidak semua memiliki fasilitas penunjang untuk bejalar online

\section{b. Tugas yang membebani}

Waktu yang diberikan untuk pengiriman jawaban dianggap terlalu cepat sehingga waktu yang dibutuhkan mahasiswa untuk memahami materi dan mengerjakan tugas menjadi beban. Tugas yang diberikan setiap matakuliah perhari 
dianggap sangat membebani mahasiswa. Mahasiswa memiliki kelas belajar tiap hari ratarata dua matakuliah dan setiap matakuliah memberikan tugas. Ada saja tugas yang diberikan tidak terdapat di materi yang disampaikan oleh dosen sehingga mahasiswa harus inisiatif mencari cara didalam penyelesaian tugas

\section{c. Biaya internet}

Mahalnya biaya akses data yang harus ditanggung mahasiswa serta beban tugas perkuliahan yang banyak ketika diterapkan kuliah online. Besarnya kuota yang dihabiskan rata-rata bervariasi dari kisaran 1 gb sampai 10 gb tergantung pemakaiannya dan media belajar yang digunakan. Kegiatan vidio konferensi akan menghabiskan kuota dengan cepat dan tugas yang sulit juga akan memakan kuota yang banyak.

Selama proses belajar mengajar dirumah, mahasiswa biasaya tidak mendapat uang harian padahal kebutuhan untuk biaya paket cukup besar. Kondisi keuangan orang tua yang tidak baik alibat pandemik covid-19 mengakibatkan kemampuan mahasiswa untuk membeli paket dinilai kurang sehingga mahasiswa ada yang terkendala ikut kuliah online dan absen.

Beberapa mahasiswa yang merantau tidak bisa pulang dikarenakan masa pandemik covid19 ini mengalami kesulitan keuangan dalam memenuhi kebutuhan hidup dan biaya internet.

\section{d. Ketersediaan layanan internet dan siyal operator yang tidak stabil}

Ketersediaan layanan internet disetiap daerah berbeda-beda disesuaikan dengan operator yang tersedia, jika mahasiswa pulang kampung maka kendala yang paling utama adalah mendapatkan layanan internet dan sinyal yang kuat .Beberapa jaringan seluler ada yang dapat aktif didesa tetapi jika ingin membeli kuota harganya cukup mahal.

Kondisi jaringan yang tidak stabil mengakibatkan kelas online yang dilakukan oleh dosen sering sekali mengalami ganguan. Jaringan yang tidak stabil mengakibatkan proses belajar mengajar menjadi terkendala hal ini disebabkan beberapa operator telepon tidak memiliki siyal yang bagus dibeberpa tempat. Bahkan beberapa mahasiswa harus mencari tempat yang memiliki siyal kuat, meminjam wifi tetangga dan teman agar proses belajar mengajar dan pengerjaan tugas dapat berjalan dengan baik.

Keluhan mahasiswa yang berada didesa bahwa proses belajar mengajar dengan online seperti webinar tidak dapat dilaksanakan dikarenakan sinyal yang kurang baik. Informasi tentang perkuliahan juga sering kali terlambat jika layanan internet tidak ada. Kondisi cuaca seperti hujan dan mati lampu juga mempengaruhi kelancaran proses belajar mengajar.

\section{e. Batas waktu tugas dan kuis}

Batas waktu tugas dan kuis yang diberikan cukup membebani mahasiswa dimana beberapa mahasiswa merasa materi yang disampaikan sulit dipahami, sedangkan waktu yang diberikan untuk mengerjakan tugas dan kuis cukup singkat sesuai dengan waktu kelas tatap muka. Kehadiran saat online yang tidak tepat waktu juga dianggap sebagai kendala karena akan ketinggalan materi pelajaran dan dianggap absen mengikuti pelajaran

\section{f. Adanya gangguan tugas rumah yang diberikan orang tua}

Saat kuliah online mahasiswa dianggap tidak produktif oleh orang tua dan sering kali orangtua menganggap mahasiswa sedang bermedia sosial seperti instagram, facebook tiktok dan dianggap bermalas-malasan.

\section{g. Disiplin waktu proses belajar mengajar}

Pengajar yang tidak tepat waktu saat kelas dimulai mengakibatkan mahasiswa harus menunggu Beberapa mahasiswa juga tidak bisa tepat waktu mengikuti kelas online dikarenakan harus membantu orangtua terlebih dahulu atau karena tidak adanya sinyal telepon.

\section{h. Kesehatan}

Beberapa mahasiswa mengeluh dengan kondisi kesehatan mata, hal ini disebabkan waktu yang mereka butuhkan untuk belajar online didepan latop dan layar handphone cukup lama. Mahasiswa menjadi mudah stress dikarenakan tugas yang begitu banyak tiap pelajaran jauh berbeda saat kuliah tatap muka.

\section{i. Kurang Empati}

Beberapa dosen dianggap kurang empati didalam mendidik mahasiswa, beberapa dosen tidak memberikan kelonggaran didalam pengerjaan tugas dan tidakmemperhatikan 
kondisi ekonomi mahasiswa yang tidak baik. Pihak kampus juga diharapkan memberikan solusi dan bantuan kepada mahasiswa untuk mengatasi persoalan ekonomi yang dihadapi oleh mahasiswa.

\section{Harapan dan Solusi}

1. Bantuan Paket, mahasiswa berharap ditengah wabah covid-19 ini pihak kampus mampu memberikan kemudahan-kemudahan agar proses belajar mengajar dapat terlaksana dengan baik, seperti pemberian kuota internet atau kebijakan biaya uang kuliah. Pengurangan uang kuliah selama masa pandemik covid-19 dianggap sangat membantu mahasiswa. Alasan lain pengurangan biaya uang kuliah disebabkan mahasiswa merasa tidak menggunakan fasilitas kampus selama pandemik covid-19.

2. Adanya dukungan dan bantuan pihak kampus dalam memberikan solusi atas kondisi perekonomian orangtua mahasiswa khususnya mahasiswa yang terdampak masa pandemik covid-19.

3. Adanya arahan yang jelas dari pihak kampus kepada para pengajar didalam melaksanakan kegiatan proses belajar mengajar secara online sehingga pengajar dapat memahami mahasiswa dan menyelesaikan persoalanpersoalan selama kelas online.

4. Adaya aturan-aturan yang mendukung proses belajar-mengajar selama masa pandemik covid-19 dan tidak terlalu kaku. Lebih peka dan peduli terhadap kondisi mahasiswa.

5. Para pengajar mampu memberikan motivasi kepada mahasiswa selama proses belajar . Pengajar lebih kreatif dan inovatif sehingga proses kegiatan belajar mengajar tidak membosankan.

6. Komunikasi yang baik antara pengajar dan mahasiswa didalam penjelasan materi yang tidak dimengerti. Adanya waktu yang disediakan oleh pengajar kepada mahasiswa untuk mendapatkan bimbingan langsung jika materi yang disampaikan tidak dipahami oleh mahasiswa.

7. Materi yang disampaikan perlu ditambahi dengan referensi lain seperti buku bacaan, video pembelajaran, audio dan referensi lain yang mendukung materi yang disampaikaan sehingga mahasiswa lebih mudah memahami materi yang disampaikan.

8. Perlunya pemahaman orang tua dalam mendukung mahasiswa saat proses belajar mengajar jarak jauh sehingga mahasiswa mampu menyelesaikan proses belajar dengan baik.

9. Pembelajaran dengan media online dengan memberikan materi kuliah dan mengerjakan soal dianggap mahasiswa kurang efektif karena dianggap kurang menarik dan sulit dipahami, Sehingga perlunya dosen aktif untuk memantau proses belajar mengajar selama kuliah online. Proses pembelajaran yang interaktif dapat membantu mahasiswa didalam menyelesaikan tugas-tugasnya. Kegiatan dapat dilakukan dengan membuat diskusi kelompok, toleransi waktu bagi mahasiswa yang kesulitan sinyal dan kegiatan belajar yang tidak menjadi beban dengan cara melibatkan mahasiswa dalam pemecahan masalah, memberi peluaang bagi mahasiswa belajar secara mandiri.

\section{KESIMPULAN}

Persoalan saat proses belajar mengajar dari tatap muka menjadi daring atau online memberikan tantangan tersendiri kepada para pengajar dan mahasiswa selama kondisi pandemik covid-19 yang tidak dapat diprediksi .Kondisi ini memaksa Perguruan Tinggi tetap menerapkan protokol keselamatan kepada dosen dan mahasiswanya. Para pendidik diharapkan mampu beberikan rasa peduli dan peka terhadap kondisi mahasiswa baik secara mental maupun ekonomi. Proses belajar mengajar diharapkan menjadi proses yang menarik, tidak menjadi beban dan saling memberi dukungan sehingga tujuan dari proses belajar mengajar dapat tercapai. Pengajar perlu melakukan inovasi dan kreatifitas didalam proses pembelajaran dan memberikan referensi lain seperti buku, video pembelajaran, audio dan referensi lain untuk mendukung mahasiswa memahami materi yang disampaikan.

Kebijakan kampus juga diharapkan mampu memberikan solusi terhadap persoalanpersoalan yang dihadapi oleh mahasiswa sehingga mahasiswa mampu mengatasi kesulitan 
saat proses belajar selama kondisi pandemik covid-19.

\section{REFERENSI}

[1] Peraturan Pemerintah, "Peraturan Pemerintah Republik Indonesia tahun 2020 tentang Pembatasan Sosial Berskala Besar dalam Rangka Percepatan Penanganan Corova Virus Disease 2019 (Covid-19)," 2020.

[2] Surat Edaran Menteri Pendidikan dan Kebudayaan Republik Indonesia, "Surat Edaran Nomor 4 tahun 2020 Tentang Pelaksanaan Kebijakan Pendidikan Dalam Masa Darurat Penyebaran Coronavirus Disease (Covid-19).," 2020.

[3] Firman and S. R. Rahayu, "Pembelajaran Online di Tengah Pandemi Covid-19," Indones. J. Educ. Sci., vol. 2, no. 2, pp. 81-89, 2020, doi: 10.31605/ijes.v2i2.659.

[4] D. R. A. U. Khasanah, H. Pramudibyanto, and B. Widuroyekti, "Pendidikan Dalam Masa Pandemi Covid-19," J. Sinestesia, vol. 10, no. 1, pp. 41-48, 2020.

[5] A. Setiawan Rifqi, "Lembar Kegiatan Literasi Saintik untuk Pembelajaran Jarak Jauh Topik Penyakit Coronavirus 2019 (COVID-19)," Edukatif J. Ilmu Pendidik., vol. 2, no. 1, pp. 28-36, 2020.

[6] R. H. S. Aji, "Dampak Covid-19 pada Pendidikan di Indonesia: Sekolah, Keterampilan, dan Proses Pembelajaran," SALAM J. Sos. dan Budaya Syar-i, vol. 7, no. 5, pp. 395-402, 2020, doi: 10.15408/sjsbs.v7i5.15314.

[7] Y. Pujilestari, "Dampak Positif Pembelajaran Online Dalam Sistem Pendidikan Indonesia Pasca Pandemi Covid-19," Adalah Bul. Huk. dan Keadilan, vol. 4, no. 1, pp. 49-56, 2020.

[8] W. A. F. Dewi, "Dampak Covid-19 terhadap Implementasi Pembelajaran Daring Di Sekolah Dasar," Edukatif J.
Ilmu Pendidik., vol. 2, no. 1, pp. 55-61, 2020. 